University of Montana

ScholarWorks at University of Montana

\title{
Reproductive Biology of the Violet-Chested Hummingbird in Venezuela and Comparisons with Other Tropical and Temperate Hummingbirds
}

\author{
Karolina Fierro-Calderon \\ Thomas E. Martin \\ University of Montana - Missoula, tom.martin@umontana.edu
}

Follow this and additional works at: https://scholarworks.umt.edu/wildbio_pubs

Part of the Life Sciences Commons

Let us know how access to this document benefits you.

\section{Recommended Citation}

Fierro-Calderon, Karolina and Martin, Thomas E., "Reproductive Biology of the Violet-Chested Hummingbird in Venezuela and Comparisons with Other Tropical and Temperate Hummingbirds" (2007). Wildlife Biology Faculty Publications. 40.

https://scholarworks.umt.edu/wildbio_pubs/40

This Article is brought to you for free and open access by the Wildlife Biology at ScholarWorks at University of Montana. It has been accepted for inclusion in Wildlife Biology Faculty Publications by an authorized administrator of ScholarWorks at University of Montana. For more information, please contact scholarworks@mso.umt.edu. 


\title{
REPRODUCTIVE BIOLOGY OF THE VIOLET-CHESTED HUMMINGBIRD IN VENEZUELA AND COMPARISONS WITH OTHER TROPICAL AND TEMPERATE HUMMINGBIRDS
}

\author{
Karolina Fierro-CALderón ${ }^{1}$ AND ThOmas E. MARTIN \\ U.S. Geological Survey Montana Cooperative Wildlife Research Unit, University of Montana, \\ Missoula, MT 59812
}

\begin{abstract}
We provide details on the breeding biology of the Violet-chested Hummingbird (Sternoclyta cyanopectus) based on 67 nests studied in Yacambú National Park, Venezuela, from 2002 through 2006. Clutch size was two white eggs, usually laid every other day. Fresh egg mass $(0.95 \pm 0.14 \mathrm{~g})$ was $15 \%$ of female mass. Incubation and nestling periods were $20.4 \pm 0.3$ and $26.0 \pm 0.4$ days, respectively. Nest attentiveness increased from $60 \%$ in early incubation to $68 \%$ in late incubation. The female spent $50 \%$ of her time brooding young nestlings, but ceased brooding by 13 days of age. Only the female fed the young, with a low rate of nest visitation (3.3 trips per hour) that did not increase with age of the young. Growth rate based on nestling mass $(K=0.28)$ was slow. Daily predation rates decreased across stages and were $0.064 \pm 0.044,0.033$ \pm 0.008 , and $0.020 \pm 0.006$ during the egg-laying, incubation, and nestling periods, respectively. Most, but not all, life history traits of the Violet-chested Hummingbird were similar to those reported for other tropical and temperate hummingbirds, providing further evidence that this family shows a relatively narrow range of life history variation.
\end{abstract}

Key words: reproductive biology, Sternoclyta cyanopectus, tropical hummingbirds.

\section{Biología Reproductiva de Sternoclyta cyanopectus en Venezuela y Comparaciones con Otros Colibríes de Zonas Tropicales y Templadas}

Resumen. Nuestro estudio provee detalles sobre la biología reproductiva del colibrí Sternoclyta cyanopectus ( $n=67$ nidos) en el Parque Nacional Yacambú, Venezuela, durante las temporadas reproductivas de 2002 a 2006. La hembra puso siempre dos huevos blancos y ovalados, usualmente cada dos días. Los huevos frescos $(0.95 \pm 0.14 \mathrm{~g})$ representaron un $15 \%$ de la masa de la hembra. Los periodos de incubación y de polluelos fueron de $20.4 \pm 0.3 \mathrm{y}$ $26.0 \pm 0.4$ días, respectivamente. La atención al nido

Manuscript received 28 December 2006; accepted 23 April 2007.

${ }^{1}$ E-mail: kavafiana@yahoo.com incrementó desde un $60 \%$ durante la incubación temprana a un $68 \%$ durante la incubación tardía. La hembra invirtió el $50 \%$ de su tiempo en empollar, pero se detuvo a los 13 días de edad de los huevos o antes. Sólo la hembra alimentó a los polluelos, con una tasa de alimentación baja (3.3 veces por hora) que no incrementó con la edad de los polluelos. La tasa de crecimiento con base en la masa $(K=0.28)$ fue lenta. Las tasas de depredación diaria fueron $0.064 \pm 0.044,0.033 \pm 0.008$ y $0.020 \pm 0.006$ durante los periodos de postura, incubación y polluelos, respectivamente. Nuestros datos proveen evidencia de un rango de variación relativamente estrecho en la biología reproductiva de la familia Trochilidae.

With 328 species, hummingbirds are one of the most diverse avian families in the New World (del Hoyo et al. 1999). Reproductive traits such as nest characteristics, clutch size, incubation period, and nestling period have been established for many temperate and tropical species. However, traits such as nest attentiveness, brooding behavior, and nestling feeding and growth rates are poorly described (Skutch 1931, 1958, 1961, Haverschmidt 1952, Wolf and Wolf 1971, Oniki and Antunes 1998). Limited components of reproductive biology have been studied in only a small fraction of the great diversity of tropical hummingbirds and studies of additional species are needed to more fully characterize the range of variation.

Here, we report the first study of the reproductive biology of the Violet-chested Hummingbird (Sternoclyta cyanopectus), one of three endemic hummingbirds in Venezuela and a monotypic genus. Global population size and trends have not been quantified, but the species is not believed to meet the population decline criterion of the IUCN Red List; therefore, Violet-chested Hummingbirds are evaluated as a species of Least Concern (IUCN 2006).

The Violet-chested Hummingbird is found in northern Venezuela, in the Andes of Táchira, Mérida, and Lara states and the coastal mountains east to Miranda (del Hoyo et al. 1999). It inhabits humid and wet premontane forest from 700 to $2000 \mathrm{~m}$ elevation, and also occurs along forest borders and in overgrown coffee plantations (Hilty 2003). 


\section{METHODS}

We conducted this study at Yacambú National Park $\left(09^{\circ} 42^{\prime} \mathrm{N}, 69^{\circ} 42^{\prime} \mathrm{W}\right)$ in Lara State of the northern Andes of Venezuela. The park covers an area of 14580 ha from 500 to $2200 \mathrm{~m}$ elevation, but we restricted our study to $1350-2000 \mathrm{~m}$ elevation. The park encompasses a mountainous area with thick vegetation of mostly primary and some secondary forest. The rainfall pattern is unimodal with a peak from May to July and an annual mean precipitation of $2047 \mathrm{~mm}$.

We searched for nests in the five breeding seasons (March to July) of 2002 to 2006. We found nests by following individuals with nesting material, which was relatively easy given that males and females were very noisy. We measured nest size using a ruler for outer diameter (from edge to edge), inner diameter (cup), outer height (exterior bottom to top) and inner height (bottom to top of cup). We weighed eggs and nestlings using an ACCULAB (Elk Grove, Illinois) portable electronic scale with an accuracy of $\pm 0.001 \mathrm{~g}$ (Martin et al. 2006), and measured nestlings (i.e., tarsus length, wing chord) using Mitutoyo (Kingsport, Tennessee) digital calipers. We checked nests every other day to determine status, except when a transition between nest stages was expected, when we checked nests daily or twice daily (Martin 2002). We calculated the duration of the incubation period as the number of days between the last egg being laid and the last egg hatching (Briskie and Sealy 1990, Martin 2002), and the nestling period as the number of days from the last egg hatching to the last nestling fledging. We measured clutch size as the number of eggs that did not change between two nest checks after completion of laying (Martin 2002).

We videotaped nests for $6-8 \mathrm{hr}$ starting within 30 min of sunrise for each videotaping event (Martin et al. 2000, Martin 2002). Videocameras were left unattended $2-10 \mathrm{~m}$ from the nest to avoid behavioral disturbance; the camera was camouflaged with a cover and the tripod was hidden by natural vegetation. We videotaped parental behaviors early (on day 2 or 3 ) and late (2-3 day before average hatching date) in incubation, and opportunistically throughout incubation for nests found after egg-laying (Martin 2002). We also videotaped parental behavior during the nestling stage, at days $2-3$, on the day that pin feathers broke their sheaths, and 2-3 day prior to the average fledging date (Martin et al. 2000). We analyzed videotapes to determine the percentage of time spent on and off the nest, nest attentiveness (percent time spent on the nest during incubation), brooding (percent time spent brooding nestlings), and feeding rate at each age. We used measurements of mass and wing chord to estimate the growth rate of nestlings as described by Remeš and Martin (2002). We calculated nest predation and nest survival rates for each nesting stage using the Mayfield method (Mayfield 1961, 1975, Hensler and Nichols 1981). All means are accompanied by their standard error (SE) as a measure of variation.
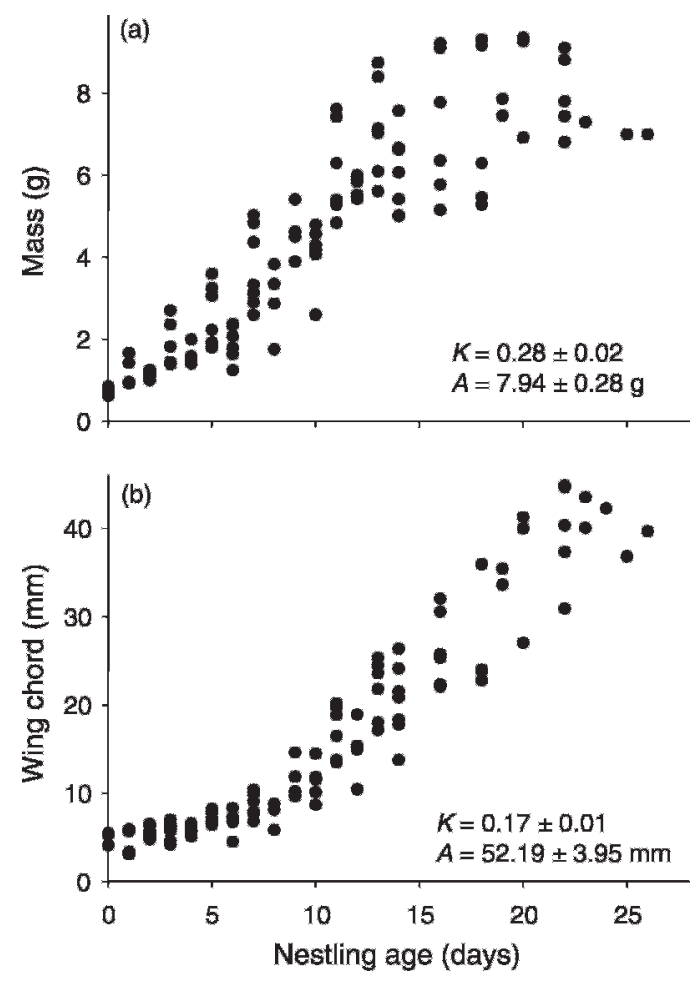

FIGURE 1. Measurements of (a) mass and (b) wing chord plotted against age for Violet-chested Hummingbird nestlings from 10 nests in Yacambú National Park, Venezuela. Growth rate constant $(K)$ and asymptote $(A)$ are indicated on each graph. Note that the asymptote for wing chord has not been reached by 25 day of age and remains much shorter than adult length.

\section{RESULTS}

We found 67 Violet-chested Hummingbird nests from 2002 through 2006. Nests were open cups with an inner layer composed of soft plant materials, probably fibers of the Bombacaceae family, and an outer layer built with a combination of moss, tree fern (Cyathea sp.) scales, spider webs, and small pieces of lichen. The size of 38 nests averaged $3.2 \pm$ $0.1 \mathrm{~cm}$ inner diameter, $4.9 \pm 0.1 \mathrm{~cm}$ outer diameter, $1.9 \pm 0.1 \mathrm{~cm}$ inner height, and $5.8 \pm 0.2 \mathrm{~cm}$ outer height.

Females alone built nests, incubated, and cared for young. Females brought nest materials and continued construction until late in the incubation period. Females adjusted materials inside the nest with fast foot movements, and they attached bits of moss and spider webs by lateral head movements around the nest. Nests were placed on average $1.9 \pm 0.1 \mathrm{~m}$ above ground $(n=65)$, sometimes on thin vines and small ferns, but usually in the forks of branches of various tree species. In two cases, a female built a new nest on an old nest, possibly from the previous season. 


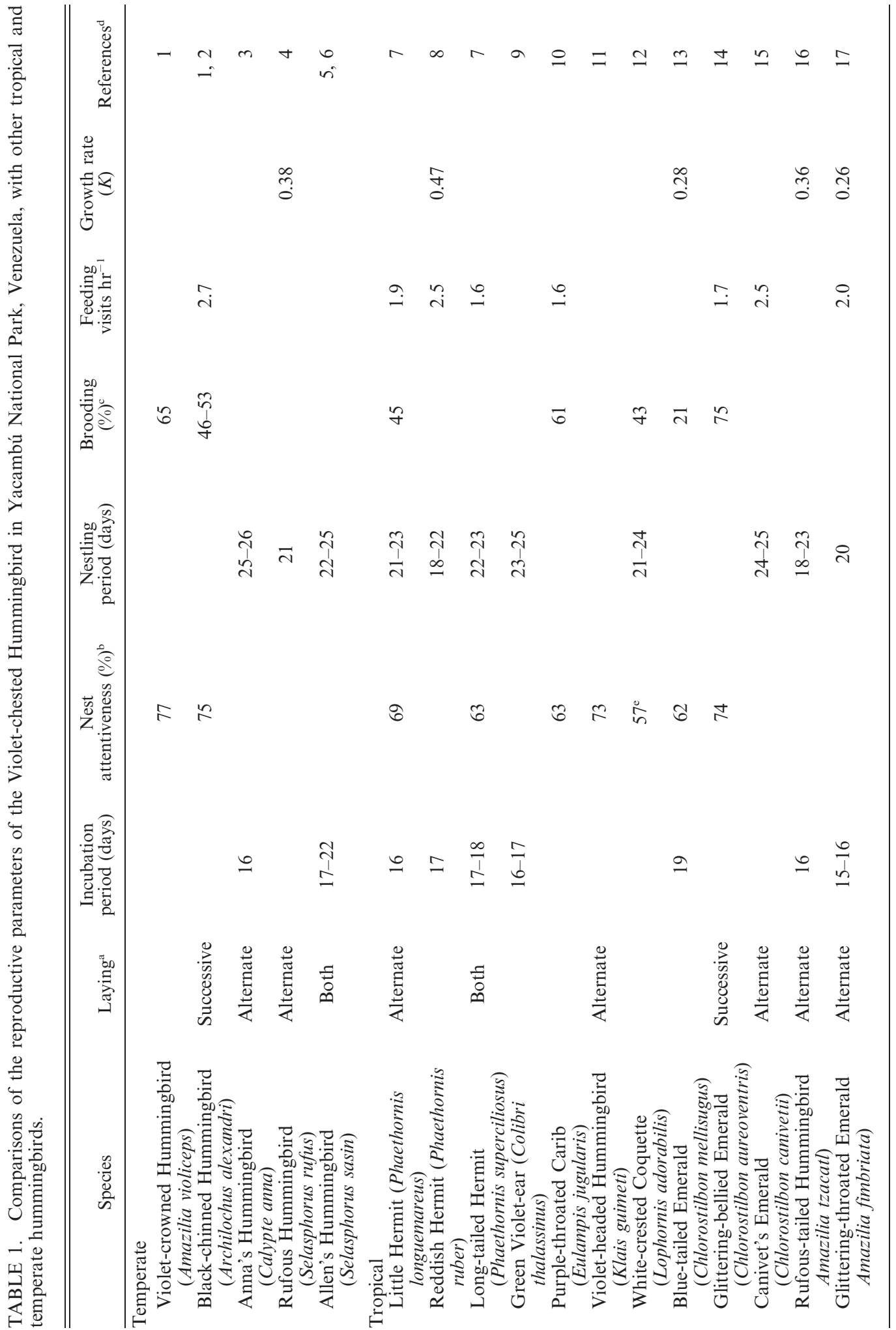




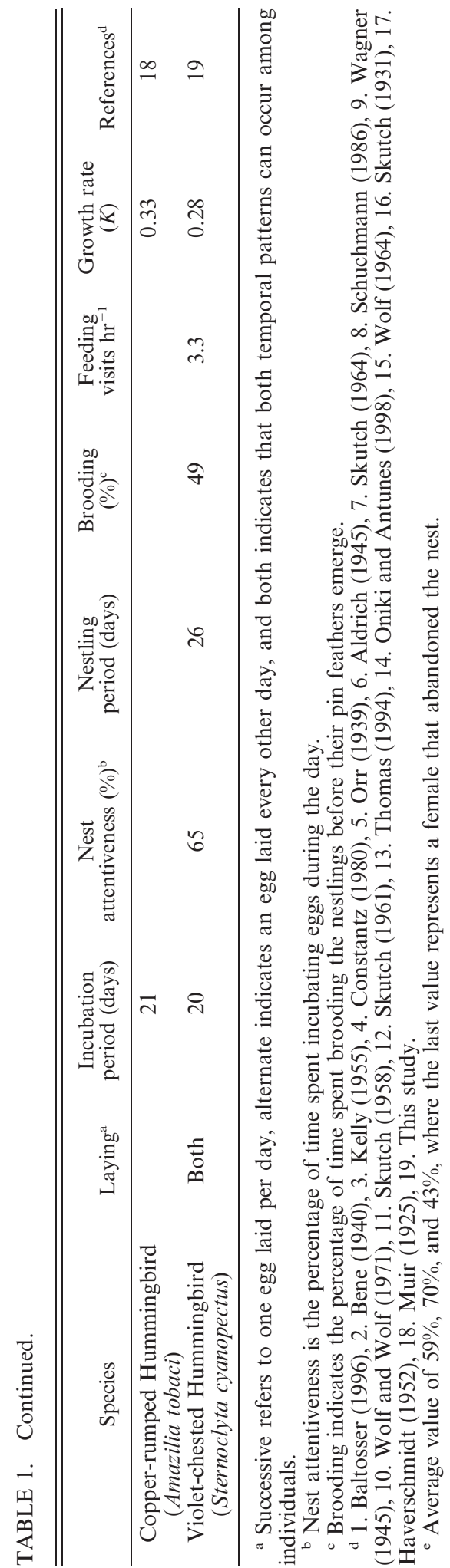

Clutch size was always two white eggs of an elliptical shape $(n=42)$. Egg mass averaged $0.95 \pm$ $0.14 \mathrm{~g}(n=25)$ during early incubation (days $0-6$ of the incubation period $), 0.80 \pm 0.19 \mathrm{~g}(n=6)$ in midincubation (days 7-13), and $0.72 \pm 0.33 \mathrm{~g}(n=4)$ during late incubation (days 14-20). Hence, eggs lost $24 \%$ of their mass between early and late incubation. Seven females laid the two eggs every other day (on alternate days), while only one laid her two eggs on successive days. Adult females captured in mist nets averaged $6.6 \pm 0.3 \mathrm{~g}(n=10)$ and the one male captured weighed $7.0 \mathrm{~g}$. Therefore, fresh egg mass was approximately $15 \%$ of female mass.

The incubation period was $20.4 \pm 0.3$ day $(n=5)$. Nest attentiveness increased slightly over the incubation period, from $60 \% \pm 2 \%(n=9$ nests) during early incubation, to $68 \% \pm 1 \%(n=3)$ in midincubation, and $68 \% \pm 3 \%(n=7)$ during late incubation (ANOVA, $F_{2,16}=5.3, P=0.02$ ). Length of bouts spent on the nest averaged $13.7 \pm 3.0 \mathrm{~min}(n$ $=9$ nests), $11.9 \pm 0.9 \mathrm{~min}(n=3)$, and $12.0 \pm$ $1.0 \mathrm{~min}(n=7)$ during early, mid, and late incubation, respectively, while length of bouts spent off the nest averaged $8.4 \pm 1.6 \mathrm{~min}(n=9), 5.5 \pm$ $0.1 \mathrm{~min}(n=3)$, and $5.7 \pm 0.9 \mathrm{~min}(n=7)$, respectively.

Nestlings hatched synchronously and remained in the nest for $26.0 \pm 0.4$ days $(n=7)$. At day 0 , they had down feathers on their backs and weighed $0.75 \pm$ $0.03 \mathrm{~g}(n=5)$. Primary feathers broke their sheaths at 15-17 days of age when pins averaged $26.4 \pm$ $1.7 \mathrm{~mm}$ in length and nestlings weighed $7.23 \pm 0.70 \mathrm{~g}$ $(n=6)$, exceeding the female's weight. Growth rate was relatively slow, but the estimated asymptote of nestling mass exceeded the mass of adult females (Fig. 1a, Table 1). Indeed, when nestlings left the nest they averaged $7.15 \pm 0.09 \mathrm{~g}(n=4)$, which exceeded female mass. The estimated asymptote for wing chords (Fig. 1b) was shorter than the $63.4 \pm$ $0.9 \mathrm{~mm}$ of adults $(n=5)$, reflecting that wing chords at fledging $(40.5 \pm 1.2 \mathrm{~mm} ; n=5)$ were much shorter than adult length and were still growing. The average percentage of time that females spent brooding nestlings during the early (days 2-3) nestling stage was $50 \% \pm 5 \%(n=5)$. Brooding ceased altogether by day 13 (Fig. 2a). Females visited the nest to feed nestlings at an average rate of $3.3 \pm 0.3$ trips per hour $(n=9$ nests) and feeding rate did not increase with age of nestlings (Fig. 2b).

Predation was the main cause of nest failure for Violet-chested Hummingbirds in Yacambú National Park. Twenty-seven nests $(40 \%)$ failed due to predation and another 11 nests $(16 \%)$ were lost to weather, abandonment, or unknown causes. One, four, and six nests failed due to causes other than predation during the laying, incubation, and nestling period, respectively. Two, 15, and 10 nests were lost to predation during the laying, incubation and nestling period, respectively. Predation rates decreased and survival increased throughout nesting. Daily predation rates were $0.064 \pm 0.044,0.033 \pm$ 0.008 , and $0.020 \pm 0.006$ during the egg-laying, incubation, and nestling periods, respectively, and $0.027 \pm 0.005$ overall. Daily survival rates were 0.903 $\pm 0.053,0.958 \pm 0.009$, and $0.968 \pm 0.008$ during the 
egg-laying, incubation, and nestling periods, respectively, and $0.962 \pm 0.006$ overall.

\section{DISCUSSION}

Much of the breeding biology of the Violet-chested Hummingbird in Yacambú National Park is similar to that described for other tropical hummingbirds: a cup-shaped nest built with soft material, moss, and spider webs, and decorated with lichens (del Hoyo et al. 1999), two white, elliptical eggs laid on successive or alternate days (Muir 1925, Skutch 1931, 1958, Haverschmidt 1952, Wolf 1964, Oniki and Antunes 1998, Sánchez et al. 2000), and incubation and nestling periods lasting 15-22 and 18-26 days, respectively (Muir 1925, Skutch 1931, 1961, Wagner 1945, Haverschmidt 1952, Wolf 1964). Violet-chested Hummingbirds were at the slow end of the developmental spectrum compared with other species, exhibiting relatively long incubation and nestling periods, and slow nestling growth rates (Table 1). Incubation and nestling periods are often longer, and growth rates are slower, in tropical birds than north temperate birds (Skutch 1949, 1985, Ricklefs 1968, 1976, Martin 2002). However, Woods (1927) was among the first to comment on the uniformity of general life-history traits among hummingbirds across latitudes and our observations further suggest that tropical and temperate hummingbirds overlap in developmental periods and other life history traits (Table 1). Growth rate based on mass for Violetchested Hummingbirds was within the substantial range of other tropical hummingbirds (Table 1). A growth rate estimate was found for only a single temperate hummingbird species, but this also was within the range documented for tropical hummingbirds, although faster than that for Violet-chested Hummingbirds (Table 1).

Nest attentiveness varied from $62 \%$ to $77 \%$ for both temperate and tropical hummingbirds (Table 1), with just two reports of lower levels of $43 \%$ and $53 \%$, both for White-crested Coquettes (Lophornis adorabilis; Skutch 1961). The authors of studies on other species did not identify the stage of incubation when the data were obtained. Nonetheless, nest attentiveness in the Violet-chested Hummingbird in each of the three stages that we assessed fit within the range of other tropical species, except the coquette, and appears to be slightly lower than that of two temperate species (Table 1), as observed generally in passerines (Martin 2002, Chalfoun and Martin 2007). Lengths of bouts on and off the nest for other hummingbirds were estimated in different ways than the method we used (Aldrich 1945, Haverschmidt 1952), so comparisons are difficult; nevertheless, our data are consistent with the results of Baltosser (1996), who demonstrated considerable uniformity in nest attentiveness and length of bouts spent on and off the nest within the Trochilidae.

The percentage of time spent brooding nestlings varied substantially among species (Table 1 ), but brooding behavior decreases with age, so comparisons among studies are difficult when ages at measurement are not reported or standardized. Violet-chested Hummingbirds spent $50 \%$ of their

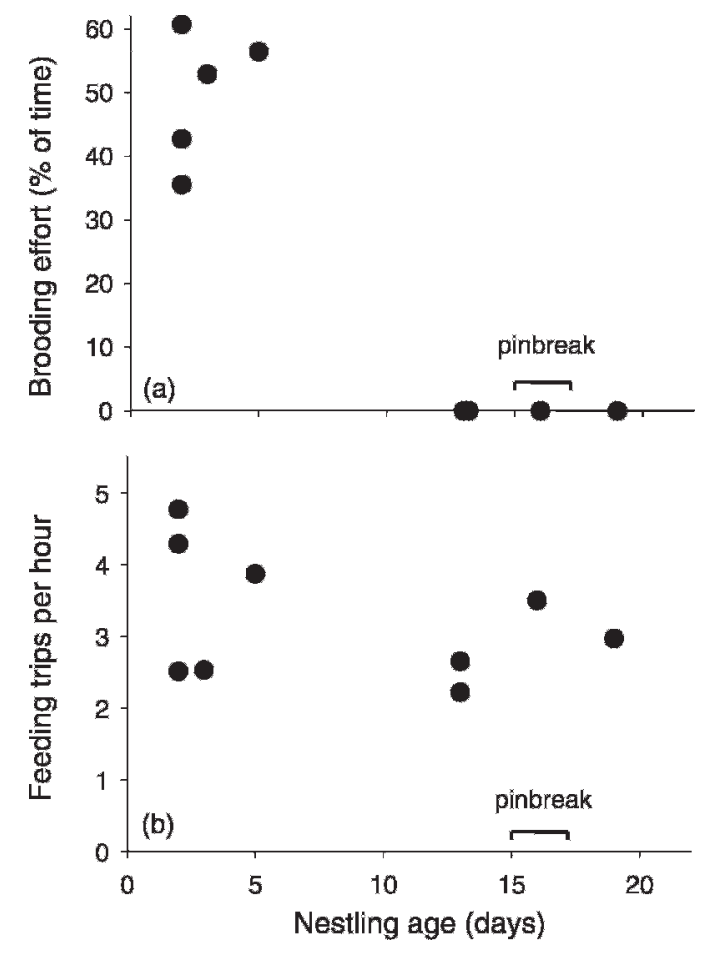

FIGURE 2. (a) Brooding effort (percentage of time spent brooding) and (b) number of nestling feeding trips per hour by Violet-chested Hummingbird females in Yacambú National Park, Venezuela. Pinbreak refers to the age when nestling pin feathers break from their sheaths.

time brooding during the early nestling stage, which was within the range of other species. Moreover, our finding that brooding behavior ceased by the middle of the nestling stage in Violet-chested Hummingbirds also has been reported in Allen's Hummingbirds (Selasphorus sasin), Green Violet-ears (Colibri thalassinus), and Blue-tailed Emeralds (Chlorostilbon mellisugus; Orr 1939, Wagner 1945, Thomas 1994).

Rates at which nestlings were fed were relatively low and similar among several hummingbirds, varying from 1.6 to 2.7 trips per hour (Table 1 ). Violet-chested Hummingbird females fed their nestlings $3.3 \pm 0.3$ times per hour, which is a slightly higher rate than documented in other species.

Our results for the Violet-chested Hummingbird provide further evidence suggesting that this family shows a relatively narrow range of variation in life history traits, even when considering geographic variation. On the other hand, the data suggest that some traits (nest attentiveness and developmental rates) show substantial variation among species, although perhaps not latitudinally, and argue for continued studies of other tropical hummingbirds.

This study was made possible in part by support from National Science Foundation grants DEB- 
9981527 and DEB-0543178 to TEM. This work was conducted under permit numbers DM/00000455 from Fondo Nacional de Ciencia, Tecnología e Innovación, PA-INP-0072.003 from Instituto Nacional de Parques, and 01-03-03-1147 from Ministerio del Ambiente. We thank K. Decker for assistance with data management, and E. Arriero, A. Niklison, D. Barton, M. J. Foguet, and two anonymous reviewers for their comments on earlier drafts of this manuscript.

\section{LITERATURE CITED}

Aldrich, E. C. 1945. Nesting of the Allen Hummingbird. Condor 47:137-148.

BAltosser, W. H. 1996. Nest attentiveness in hummingbirds. Wilson Bulletin 108:228-245.

BENE, F. 1940. Rhythm in the brooding and feeding routine of the Black-chinned Hummingbird. Condor 42:207-212.

Briskie, J., AND S. G. SEALY. 1990. Evolution of short incubation periods in the parasitic cowbirds, Molothrus spp. Auk 107:789-793.

Chalfoun, A., And T. E. Martin. 2007. Latitudinal variation in avian incubation attentiveness and an experimental test of the food limitation hypothesis. Animal Behavior 73:579-585.

Constantz, G. D. 1980. Growth of nestling Rufous Hummingbirds. Auk 97:622-624.

del Hoyo, J., A. Elliott, and J. Sargatal [eds.]. 1999. Handbook of the birds of the world. Vol. 5. Lynx Edicions, Barcelona.

HAVERSCHMIDT, F. R. 1952. Notes on the life history of Amazilia fimbriata in Surinam. Wilson Bulletin 64:69-79.

Hensler, G. L., And J. D. Nichols. 1981. The Mayfield method of estimating nesting success: a model, estimators and simulation results. Wilson Bulletin 93:42-53.

Hilty, S. 2003. Birds of Venezuela. 2nd ed. Princeton University Press, Princeton, NJ.

IUCN. 2006. Sternoclyta cyanopectus. 2006 IUCN Red List of threatened species. $<$ www.iucnredlist. org > (26 April 2007).

Kelly, J. W. 1955. History of the nesting of an Anna Hummingbird. Condor 57:347-353.

MARTIN, T. E. 2002. A new view for avian life history evolution tested on an incubation paradox. Proceedings of the Royal Society of London Series B 269:309-316.

Martin, T. E., R. D. Bassar, S. K. Auer, J. J. Fontaine, P. Lloyd, H. A. Mathewson, A. Niklison, AND A. Chalfoun. 2006. Geographic variation in egg size and clutch mass among passerine species. Evolution 60:390-398.

Martin, T. E., P. R. Martin, C. R. Olson, B. J. Heidinger, And J. J. Fontaine. 2000. Parental care and clutch sizes in North and South American birds. Science 287:1482-1485.
MAYFIELD, H. 1961. Nesting success calculated from exposure. Wilson Bulletin 73:255-261.

MAYFIELD, H. 1975. Suggestions for calculating nest success. Wilson Bulletin 87:456-466.

Muir, A. 1925. The nesting of the Emerald Hummingbird (Saucerottia tobaci erythronota) in Trinidad. Ibis 67:648-654.

ONIKI, Y., AND A. Z. ANTUNES. 1998. On two nests of the Glittering-bellied Emerald Chlorostilbon aureoventris (Trochilidae). Ornitología Neotropical 9:71-76.

ORR, R. T. 1939. Observations on the nesting of the Allen Hummingbird. Condor 41:17-24.

REMEŠ, V., AND T. E. MARTIN. 2002. Environmental influences on the evolution of growth and developmental rates in passerines. Evolution 56:2505-2518.

RICKLEFS, R. E. 1968. Patterns of growth in birds. Ibis 110:419-451.

RICKLEFS, R. E. 1976. Growth rates of birds in the humid New World tropics. Ibis 118:179-207.

SÁnchez, J. E., R. S. Mulvihill, AND T. L. MASTER. 2000. First description of the nest and eggs of the Green-crowned Brilliant (Heliodoxa jacula), with some behavioral notes. Ornitología Neotropical 11:189-196.

SCHUCHMANN, K. L. 1986. Natal care and growth in a nestling Reddish Hermit Phaethornis ruber in Surinam. Ardea 74:101-104.

SkUTCH, A. F. 1931. The life history of Rieffer's Hummingbird (Amazilia tzacatl tzacatl) in Panamá and Honduras. Auk 48:481-500.

SkUTCH, A. F. 1949. Do tropical birds rear as many young as they can nourish? Ibis 91:430-455.

SkUTCH, A. F. 1958. Life history of the Violetheaded Hummingbird. Wilson Bulletin 70:5-19.

SkUTCH, A. F. 1961. Life history of the Whitecrested Coquette Hummingbird. Wilson Bulletin 73:5-10.

SkUTCH, A. F. 1964. Life histories of Hermit Hummingbirds. Auk 81:5-25.

SkUTCH, A. F. 1985. Clutch size, nesting success, and predation on nests of Neotropical birds, reviewed. Ornithological Monographs 36:575594.

Thomas, B. T. 1994. Blue-tailed Emerald Hummingbird (Chlorostilbon mellisugus) nesting and nestling development. Ornitología Neotropical 5:57-60.

WAGNER, H. O. 1945. Notes on the life history of the Mexican Violet-ear. Wilson Bulletin 57:165-187.

Wolf, L. L. 1964. Nesting of the Fork-tailed Emerald in Oaxaca, Mexico. Condor 66:51-55.

Wolf, L. L., AND J. S. Wolf. 1971. Nesting of the Purple-throated Carib Hummingbird. Ibis 113:306-315.

Woods, R. S. 1927. The hummingbirds of California. Auk 44:297-318. 